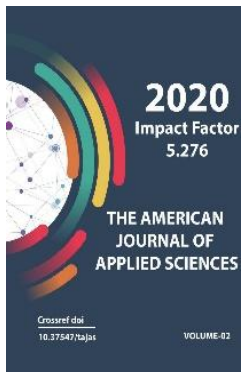

Journal Website: http://usajournalshub.c om/index,php/tajas

Copyright: Original content from this work may be used under the terms of the creative commons attributes 4.0 licence.

\section{Use Of Recovery Boilers At Gas-Turbine Installations Of Compressor Stations And Thyristor Controls}

\author{
Arzikulov Fazliddin \\ Jizzakh Polytechnic Institute, 3rd Year Student Of The Department Of Electrical Engineering, \\ Jizzakh City, Uzbekistan \\ Sadullayev Tuymurod \\ Jizzakh Polytechnic Institute Assistant Of The Department Of Electric Power, Jizzakh City, \\ Uzbekistan \\ Olimov Orif Nosirovich \\ Jizzakh Polytechnic Institute, Assistant Of The Department Of Electric Power, Jizzakh City, \\ Uzbekistan
}

\title{
ABSTRACT
}

The article discusses options for utilizing heat from the exhaust gases of gas turbine plants and reducing emissions of combustion products into the environment through the use of recovery boilers. The calculation of the volume of nitrogen and triatomic gas emissions that can be avoided by using waste heat boilers to reduce the temperature of flue gases after a gas turbine installation from 500 to 1500 C.

\section{KEYWORDS}

GTI, gas pumping unit, waste-heat boiler, compressor station, combustion products, pollutant emissions, thyristor.

\section{INTRODUCTION}

When choosing the direction of energy development, the mandatory conditions are the environmental safety of the technologies used, since environmental problems are especially acute in the country's fuel and energy complex (FEC). The fuel and energy sector accounts for more than 50\% of pollutant emissions into the air. The oil and gas sector is the most energy-intensive and at the 
same time there is an insufficient level of development of energy-efficient technologies and a lack of the use of alternative energy.

\section{MATERIALS AND METHODS}

Let us consider the directions of increasing the efficiency of gas pumping units to compressor stations of gas mains, in which gas turbine drives are most widely used (Fig. 1) [1]

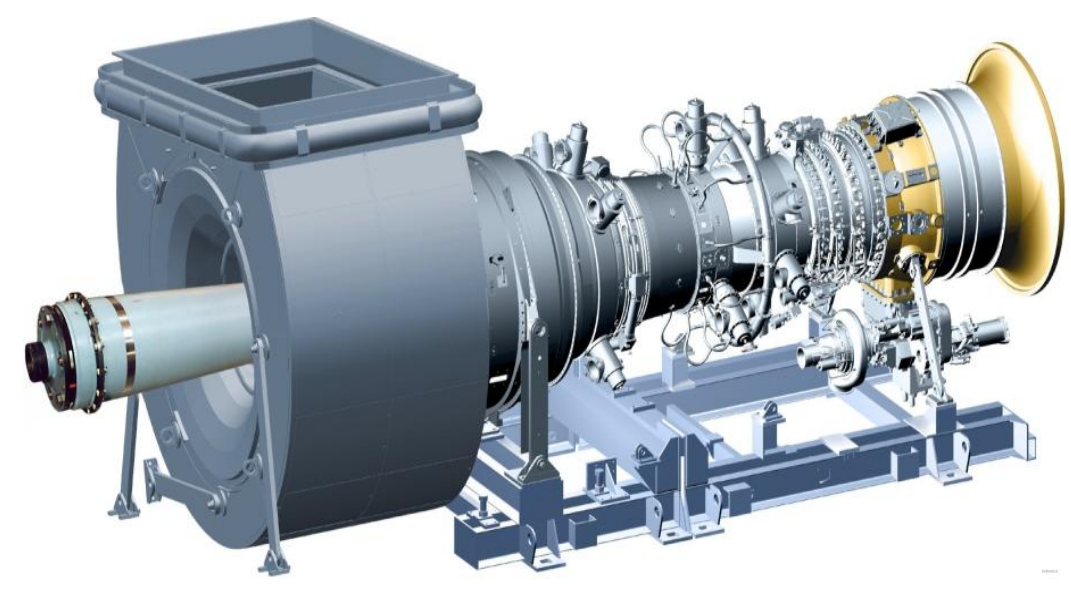

Fig.1. GTU-16P with a PS-90GP-2 engine

Fuel (refined natural gas pumped to operating pressure) is supplied to the combustion chamber, and combustion products having high temperature and pressure and having high energy form a gas stream, the energy of which is converted into mechanical work.

To build a mathematical model of electric drives, we used the MATLAB Simulink program. The issues of design and modeling of asynchronous electric motors remain very acute, since the requirements for the performance of modern electric motors have increased significantly. To solve such problems, computer-aided design systems are often used.

However, most of the models created in them are not interactive [2].In this regard, the use of the latest software products, in particular, the software module in the Simulink environment of the Matlab program, is of considerable interest. This software module is a modern tool for designing and modeling various types of electrical machines.

Table 1 shows the number and characteristics of the most common gas turbines for driving natural gas blowers [2]. 
Table 1 - Parameters of the most common GTU GPA

\begin{tabular}{|l|l|l|l|l|l|}
\hline GTU & $\begin{array}{l}\text { Number of } \\
\text { units, pcs } \\
\text { MW }\end{array}$ & $\begin{array}{l}\text { Power, } \\
\%\end{array}$ & $\begin{array}{l}\text { Efficiency } \\
\text { consumption, } \\
\mathrm{kg} / \mathrm{s}\end{array}$ & $\begin{array}{l}\text { Flue gas } \\
\text { temperature, } \\
{ }^{\circ} \mathrm{C}\end{array}$ \\
\hline GTK-10 & 646 & 10 & 32 & 86 & 303 \\
\hline NK-16ST & 618 & 16 & 29 & 103,1 & 378 \\
\hline NK-12ST & 322 & 6 & 26,1 & 57,6 & 302 \\
\hline DR-59L & 268 & 10 & 28,5 & 81,5 & 330 \\
\hline
\end{tabular}

The main trend in the development of gas turbines is an increase in the initial temperature of the gas in front of the turbine, which entails an increase in the efficiency of the plants, a decrease in the coefficient of excess air and an increase in the temperature of the exhaust gases (Table 2). It is necessary to utilize the heat contained in the flue gases, which affects not only economic but also environmental indicators.

Tab.2. Parameters of promising gas turbines

\begin{tabular}{|l|l|l|l|l|}
\hline GTU & $\begin{array}{l}\text { Power, } \\
\text { MW }\end{array}$ & $\begin{array}{l}\text { Efficiency } \\
\%\end{array}$ & $\begin{array}{l}\text { Flue gas } \\
\text { consumption, } \\
\mathrm{kg} / \mathrm{s}\end{array}$ & $\begin{array}{l}\text { Flue gas } \\
\text { temperature, } \\
\mathrm{C}\end{array}$ \\
\hline PS-90GP25 & 25 & 37,9 & 83 & 543 \\
\hline AL-31CT & 16 & 36,5 & 64,5 & 490 \\
\hline GTD-10RM & 10 & 35,5 & 33 & 518 \\
\hline
\end{tabular}

\section{RESULT AND DISCUSSION}

Consider the common technologies for heat recovery of exhaust gases from gas turbines [3]. Exhaust gases with a temperature of about $500{ }^{\circ} \mathrm{C}$ enter a heat exchanger (waste heat boiler) where they give their heat to water while cooling to $150^{\circ} \mathrm{C}$. As a result, water steam can be produced going to the steam turbine generating electric energy (Fig. 2) or hot water used for heating and hot water supply of nearby objects (Fig. 3). 


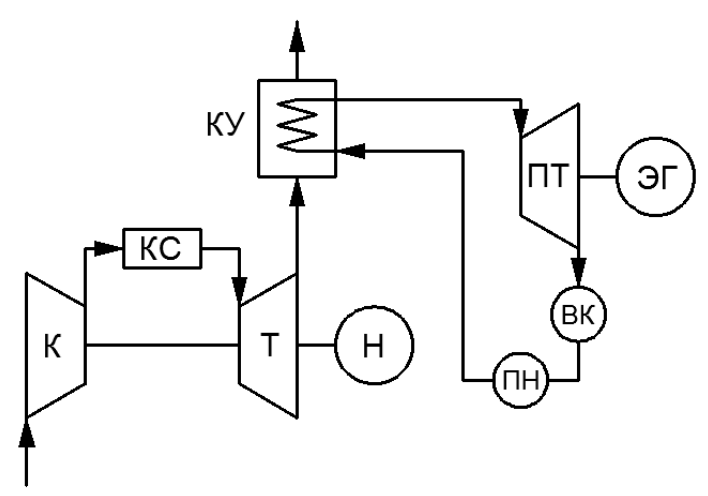

Fig.2. Scheme of a combined cycle plant:

$\mathrm{K}$ - compressor; $\mathrm{KCh}$ - combustion chamber; $\mathrm{T}$ - is a turbine; $\mathrm{H}$ - natural gas supercharger; WHB - waste heat boiler; ST - steam turbine;

$A C$ - air condenser; FP - feed pump;

EG - electric generator

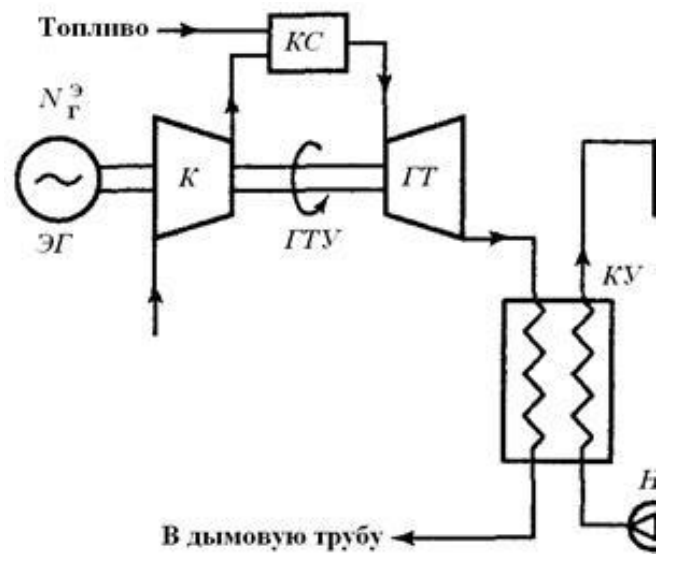

Fig.3.Scheme of a gas turbine installation with a waste heat boiler

Such seeds are improved, for example, through the use of working fluids boiling at lower temperatures or through the use of three different working fluids. But complicated schemes have the disadvantages of duly developing them: the need for investment increased operating costs, increased accidents and the need for a feasibility study.
The use of heat exchangers for heating water, in our opinion, is the most economical solution to the issue of heat recovery of combustion products.

To calculate the calorific value of gas fuel, we used the formula, where the calorific value of gas fuel is defined as the sum of the calorific value of combustible gases that make up gas fuel, according to the formula, 


$$
Q_{u}^{c}=0,01 \cdot\left(Q_{\mathrm{CH}_{4}} \mathrm{CH}_{4}+Q_{\mathrm{C}_{2} \mathrm{H}_{6}} \mathrm{C}_{2} \mathrm{H}_{6}+Q_{\mathrm{C}_{3} \mathrm{H}_{8}} \mathrm{C}_{3} \mathrm{H}_{8}+\ldots\right)(1)
$$

The calculation, respectively, of the volume of air, flue gases and water vapor (s) during stoichiometric combustion of one meter of

$$
V^{0}=0,0476\left[0,5 \mathrm{CO}+0,5 \mathrm{H}_{2}+\sum\left(m+\frac{n}{4}\right) C_{m} H_{n}-O_{2}\right]
$$

\section{CONCLUSION}

As a result of the calculations, we determined the amount of heat obtained by lowering the temperature of the combustion products (from 500 to $150 \mathrm{oC}$ ) obtained by burning $1 \mathrm{~m} 3$ of natural gas, which amounted to $12456 \mathrm{~kJ} /$ $\mathrm{m} 3$ (in the calculation the coefficient of excess air is assumed to be 2.2). To obtain such an amount of heat, it would be necessary to burn $0.325 \mathrm{~m} 3$ of gas in the boiler room and throw $2.45 \mathrm{~m} 3$ of nitrogen and $0.328 \mathrm{mz}$ of triatomic gases into the environment.

\section{REFERENCES}

1. Zaripov, Sh., Sa'dullaev, M., Sa'dullaev, T., \& Sa'dullaev, O. (2017). Razrabotka cubic gas (1 nm3 of fuel) in $\mathrm{nm}_{3} / \mathrm{nm}_{3}$ is performed according to the formulas: ratsionalnыx resheniy beskontaktnogo upravleniya elektroprivodami gornыx mashin. Sovremennыe nauchnыe issledovaniya i razrabotki, (8), 201-205.

2. Sa'dullaev, M. S., Xamzaev, A. A., Narzullaev, B.SH. \& Sa'dullaev, T.M. (2018) Ispolzovanie ustroystv, sostoyaщix iz beskontaktnыx elementov, v upravlenii kompensiruyuщimi ustroystvami. Molodoy uchenty, (1), 23-25.

3. Sadullaev T. M., Sailiev F. O. Development of optimal solutions for contactless switching for electric machines of alternating current // Young scientist. 2020. - No. 2. - S. 51-54. 